Original article

\title{
HORIZONTAL TENSIONAL STRESS AND MOUNTAIN DEVELOPMENT: IN EXAMPLE OF GILBERT RANGE AND KHUREN KHANAN RANGE, MONGOLIA
}

\author{
Sanjaa Ganbaatar* \\ Geological Investigation Center of Mongolia, Ulaanbaatar 18080, Mongolia \\ *Corresponding author.Email: s_ganbaatar2006@yahoo.com
}

\section{ARTICLE INFO}

Article history:

Received 21 March 2019

Accepted 20 April 2019

\begin{abstract}
Results of analysis of schematic geological cross section constructed using satellite image interpretation and 1:200 000 scale geological map through the Tavan Zagiin Khooloi, Gilbert Range, Dund Goliin Khooloi and Khuren Khanan Range are represented in this paper. Our results show that within the above mentioned mountain ranges decollement faults formed due to $\mathrm{S}$ to $\mathrm{N}$ trending tensional tectonic stress and, moreover, numerous thrust and back-thrust faults formed perpendicular to them. SW-NE, N-S trending tensional stresses are dominant in the western part of Mongolia and northwestern part of China. Interaction forces opposing them are the circumstances of forming new thrust faults in the Tavan Zagiin Khooloi and Dund Goliin Khooloi. Along the existing thrust faults, the Gilbert Range and Khuren Khanan Range were formed. Mountain blocks were uplifted due to the back-thrust faults and crustal thickening took place. As a result of horizontal tensional stress, the mountain development and shortening occurred.
\end{abstract}

Keywords: thrust fault, back-thrust fault, Tavan Zagiin Khooloi, Dund Goliin Khooloi

(C) The Author(s). 2019 Open access This article is distributed under the terms of the Creative Commons Attribution 4.0 International License (https://creativecommons.org/licenses/by/4.0/), which permits unrestricted use, distribution, and reproduction in any medium, provided you give appropriate credit to the original author(s) and source, provide a link to the Creative Commons license, and indicate if changes were made. 


\title{
ХЭВТЭЭ ЧИГЛЭЛТЭЙ ХУЧНИЙ ҮЙЛЧЛЭЛ БА УУЛ ҮУСЭХ ХӨДӨЛГӨӨН: ГИЛБЭРТИЙН НУРУУ, ХУРЭН ХАНАНГИЙН НУРУУНЫ ЖИШЭЭН ДЭЭР
}

\author{
Санжаагийн Ганбаатар*
}

Геологийн Судалгааны Төв ТӨҮГ, Улаанбаатар 18080, Монгол

*Email:

\section{ХУРААНГУЙ}

Таван загийн хоолой, Гилбэртийн нуруу, Дунд голын хоолой, Хүрэн ханангийн нурууг хамарсан, тэдгээрт хөндлөн буюу өргөргийн дагуу чиглэлтэй геологийн тойм зүсэлтийг сансрын зургийн тайлал, 200000 масштабтай геологийн зургууд ашиглан хийсэн ажлын үр дүнг энд үзүүлсэн болно. Геологийн тойм зүсэлтээр дээрх нэр бүхий газруудад У-Х хэвтээ чиглэлтэй шахах тектоник хүчний үйлчлэлээс үүссэн деколлемент хагарал, түүнд хөндлөн чиглэлтэй үүсч буй олон тооны тохролтот болон эсрэг тохролтот хагарлуудын үйлчлэл хэрхэн нөлөөлж байгааг тайлбарласан үр дүнг толилуулж байна. Манай орны баруун хагас, Хятадын баруун хойд хэсэгт БУ-3Х, У-Х чиглэсэн хэвтээ чиглэлтэй тектоник хүч, харин түүний эсрэг үйлчлэх тулах хүчнүүдийн харилцан үйлчлэлээс үүдэн Таван загийн хоолой, Дунд голын хоолойд шинээр тохролууд үүсч байгаа бол Гилбэрт, Хүрэн ханангийн нуруунд өмнө нь үүссэн тохролуудын дагуу хавтангууд бие биенийхээ дээгүүр давхралдах, эсрэг тохролтот хагарлаар хавтангууд дээш шахагдан гарснаар уул, нурууд улам өндөрсөж, тасралтат хавтан улам зузаарч байна. Хэвтээ чиглэлтэй шахах хүчний үйлчлэлийн үр дүнд агшилт явагдаж, өөр хоорондоо ойртож, өндөрсөж байна.

$\boldsymbol{T}_{\boldsymbol{Y}} \boldsymbol{x} \boldsymbol{Y} \boldsymbol{y} \boldsymbol{p}$ у: тохролтот хагарал, эсрэг тохролтот хагарал, Таван загийн хоолой, Дунд голын хоолой

\section{ОРШИЛ}

ЭнэхүҮ өгүүлэлтэй холбогдуулаад детачмент, деколлемент хагарлууд, түүний судалгааны талаар товч дурьдлаа. Детачмент хагарлын тухай 19-р зууны эхэн хагасын сүүл үеэс эхлэн маш олон геологичдын судалгааны материалд хэвлэгдэн гарсан байдаг (Rich, 1934 Kusky et al., 2010). Argand Escher 1841 онд Альпын ойролцоо (Argand, 1916), James M. Safford 1856 онд Америкийн Теннисс мужид (Safford, 1856), A.E.Törnebohm 1872 онд Шведэд (Törnebohm, 1872), R.G.McConnel 1887 онд Канадын Роки нуруунд (McConnell, 1887), A.Buxtorf 1907 онд Швейцар, Францын хил дээр оршдог Альпын нурууны хойд салбар Юра нуруунд (Buxtorf, 1916), А.Баясгалан нар 1995 онд Говь-Алтайн нуруунд (Bayasgalan, 1995;
Bayasgalan et al., 1997), Л.Ганбаатар 2015 онд Баруун Монголд (Ganbaatar, 2015), Хятадын баруун хойд нутагт (Tian et al., 2016), С.Бөхбат нар 1997 онд Хүрэн ханангийн нуруунд (Бөхбат нар, 1999), Г.Бадарч нар 2003 онд, Буянбаатар нар 2009 онд Баруун Өмнөд Монголд хийсэн судалгааны ажлуудад (Бадарч нар, 2003; Буянбаатар нар, 2009) хэвтээ чиглэлтэй шахах тектоник хүчний үйлчлэлийн улмаас үүссэн налуу уналтай (low angle fault) хагарлуудыг ялгаж, тэр тухай бүтээлдээ тусгасан байдаг. Өмнөд болон Баруун өмнөд монголын хэмжээнд явагдсан шинэхэн тектоник хөдөлгөөн, хагарлуудын талаар олон судлаачдын ажлууд хийгдсэн байдаг (Owen et al., 1997; Price, 1981; Woldai and Dorsjuren, 2004; Robert et al., 2007; Roberts and Cunningham, 2008; Landgraf et al, 2017). 
Монгол орны баруун, баруун өмнөд хэсэг, түүнтэй хил залгаа Хятад улсын баруун хойд хэсэгт У-Х, БУ-ЗХ чиглэлтэй шилжилтүҮд давамгайлж байдаг ба энэ хүч нь хойноос урагш чиглэлтэй хүчтэй харилцан үйлчилсэний үр дүнд газар хөдөлж байгааг сейсмо судлаач Л.Ганбаатар тогтоосон байдаг (Ganbaatar, 2015). Мөн Монгол орны баруун, баруун өмнөд хэсгийн газар нутаг бүхэлдээ У-Х, ЗУ-ЗХ чиглэлтэй тохролтот структурт өргөн өртсөн болохыг А.Баясгалан, С.Бөхбат нарын судалгааны материалд тусгагдсан байдаг (Bayasgalan, 1995; Bayasgalan et al., 1997; Woldai and Bayasgalan, 1998; Бөхбат нар, 1999).

Дэлхий дээр янз бүрийн чиглэлтэй тектоник хөдөлгөөн тасралтгүй байнга явагдаж байдаг ба түүнтэй холбоотой газрын гадаргуу байнга өөрчлөлтөд орж байдаг байна. Энэ өөрчлөлтүүд нь гагцхүҮ хөдөлгөөний хурд, хүч, чулуулгийн шинж чанараас шалтгаалж харилцан адилгүй хурдтай, харилцан адилгүй атираажил болон эвдрэл, өөрчлөлтөд өртөж байдаг байна. Хэвтээ чиглэлтэй хагарал нь хэвтээ чиглэлтэй шахагдах болон тэлэгдэх процесын үр дүнд үүсдэг. Тэлэлтийн үр дүнд үүсч буй хагарлыг детачмент, шахалтын үр дүнд үүсч буй хагарлыг деколлемент гэж нэрлэдэг байна. Судлаачид детачмент болон деколлемент хагарлыг өөр өөрөөр тайлбарлах тохиолдол байдаг. Зарим судлаачид детачмент нэрийн дор шахагдах болон тэлэгдэх процесыг хоёуланг авч үзсэн байдаг. Мөн детачмент хагарлыг далайн хавтанд, деколлемент хагарлыг тивийн хавтанд үүсдэг гэж википедиад тодорхойлон бичсэн байдаг.
Хэвтээ чиглэлтэй детачмент болон деколлемент хагарлууд нь газрын гадаргуугаас 10 км-ээс илүү гүнд үүсдэг ба хагарлын дээд тал буюу түрэгдэж, гулсаж, тасарч буй хавтанг хэврэг (brittle), доод талыг нь уян хатан хавтан (ductile) гэж нэрлэдэг. Хэвтээ хагарлын доод талын суурь хавтан нь зөвхөн түгээмэл метаморфизмд орсон чулуулгаас тогтдог бол дээд талын гулсаж буй хавтан нь түгээмэл метаморфизмд орсон болон ороогүй янз бүрийн чулуулгаас тогтсон байдаг. Детачмент хагарал нь мантийн урсгалын нөлөөгөөр литосферт үүссэн урт сунасан хагарлын бүсийн дагуу тэлэх (рифт), купол хэлбэрийн биет дээш өргөгдөхөд үүссэн хэвтээ чиглэлтэй хүчний нөлөөгөөр эвдэрсэн болон уян хатан хавтангуудын хооронд үүсч буй хагарлыг хэлэх ба түүгээр тэлэлт явагдаж, тасралтат хавтан нимгэрч байдаг. Тус хагарлын улмаас гулсаж, тасарч буй хавтанд босоодуу уналтай, олон тооны зэрэгцээ, ердийн хагарлууд үүсдэг ба цааш хөгжлийн явцад эдгээр ердийн хагарлын уналын өнцөг багасч, хэврэг хавтан улам нимгэрч байдаг. Цагираг структурууд ч үүнтэй холбоотой үүсдэг. Купол хэлбэрийн биет доороос дээш түрэхэд тэлэгдэх процесс үүсч, хэврэг хавтанд цагираг хагарлууд үүсч, тал тал тийшээ гулсалт явагдана. Деколлемент хагарал нь шургалт үүсч, агшилт явагдаж буй структурт ихэвчлэн илэрдэг. Деклоллемент хагарлын улмаас гулсаж буй хавтанд зэрэгцээ байрлалтай тохролтот хагарлууд, эсрэг тохролтот хагарлууд үүсдэг. Тохролтот хагарлууд нь уг шахах тектоник хөдөлгөөний чиглэлийн

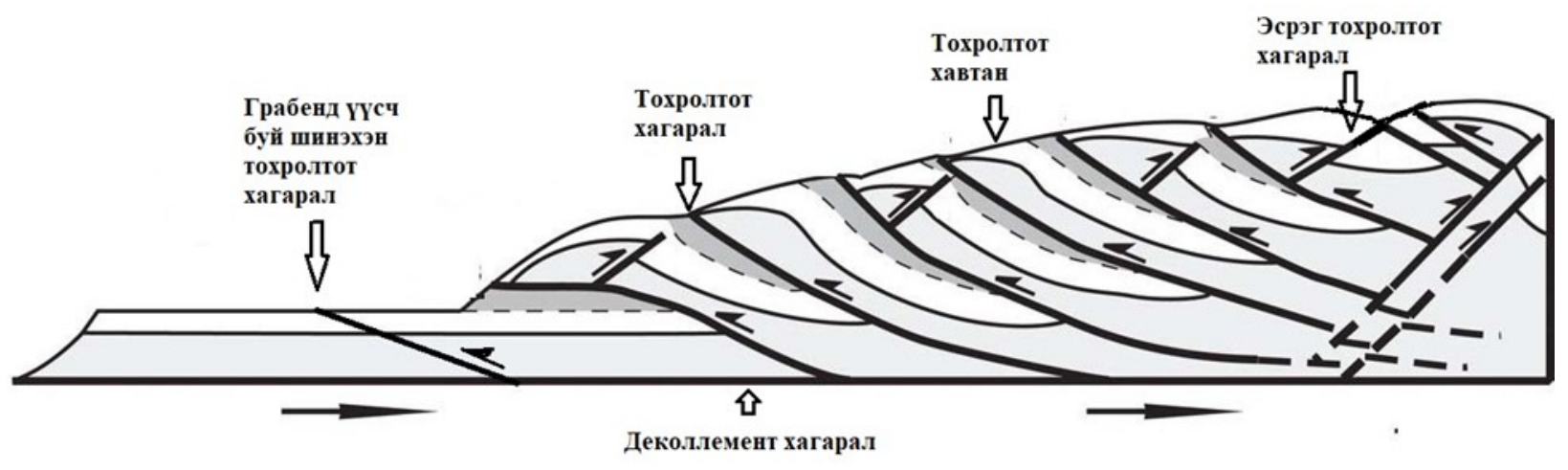

Зураг 1. Деколлемент хагарлын нөлөөгөөр үүссэн тохролтот болон эсрэг тохролтот хагарал 
эсрэг уналтай байх бол, эсрэг тохролтот хагарлын унал нь тектоник хөдөлгөөний чиглэлийн дагуу байна (Зураг 1). Шахалт үргэлжлэн явагдсанаар зэрэгцээ тохролтот хагарлаар хуваагдсан тохролтот хавтангууд (trust sheet) нь цааш бие биенийхээ дээгүүр тохорч, хавтан улам зузаарах буюу уул нурууд өндөрсөж байхад зарим газарт чулуулгийн хэв шинж чанараас хамаарч эсрэг чиглэлтэй тохролтот хагарал үүсдэг. Тохролтот болон эсрэг тохролтот хагарлуудаар тусгаарлагдсан блокууд дээш шахагдан гарч уулсыг улам өндөр болгодог. Шахагдсан блокууд голдуу уул нуруудын орой, хэцийн дагуу байна. Дээрх үйл явцтай зэрэгцэн хэвтээ байрлалтай хурдас чулуулгийн төвд шинээр тохролтот хагарлууд үүсч байгаа нь шинээр уул нурууд үүсэх эхлэл болдог байна. Манай жишээн дээр мезо-кайнозойн хурдсаар хучигдсан грабенд Үүсч буй 1-3, 6-11 дугаартай хагарлууд Үүний жишээ болно (Зураг 1, 5).

\section{СУДАЛГААНЫ АЖЛЫН ҮР ДУН}

Судалгааны талбайн нь Таван загийн хоолойгоос Гилбэртийн нуруу, Дунд голын хоолой (Гурван тэсийн давсны уурхай), Хүрэн ханангийн нуруу, түүний өвөр (Нарийн сухайтын нүүрсний уурхай), Хөхөлзөхийн говь хүртэл үргэлжилнэ (Зураг 2). Г.Бадарч нарын Баруун Өмнөд Монголын геологийн зургийн тайлбар бичиг, Буянбаатар нарын УГЗ-200 төсөл, С.Бөхбат нарын 1:200000 масштабтай геологийн зургуудыг суурь болгон (Бөхбат нар, 1999; Бадарч нар, 2003; Буянбаатар нар, 2010), сансрын зурагт хийсэн тайлал ашиглан нийт 14 тохролтот хагарлыг хамруулан (Зураг 3), тэдгээр хагаралд хөндлөн, Х-У чиглэлд хийсэн геологийн тойм зүсэлт зохиолоо (Зураг 4). Гилбэрт, Хүрэн ханангийн нуруунд маш олон налуу болон босоо уналтай, ихэвчлэн уртрагийн дагуу болон БХ, 3Х чиглэлтэй хагарлууд байгаа ч энд зөвхөн сайн тайлагдаж буй уртрагийн дагуух чиглэлтэй цөөн тооны налуу уналтай хагарлыг төлөөлөл болгон тойм зүсэлтэд харуулсан болно (Зураг 4).

Гилбэртийн нуруу, Дунд голын хоолой,
Хүрэн ханангийн нуруу, Хөхөлзөхийн говийн хотгор структур (Foreland) нь баруунаас зүүн тийш буюу уртрагийн чиглэлтэй хэдэн зуун км урт үргэлжилсэн уул нурууд (Гилбэртийн нуруу Хүрэн ханангийн нуруу), түүнтэй зэрэгцээ байрлах, өргөн хөндийнүүдийн (Дунд голын хоолой, Хөхөлзөхийн говь) хослолоос тогтоно. У-Х чиглэлтэй хэвтээ чиглэлд шахах тектоник хүчний үйлчлэлээр үүссэн деколлемент хагарлын улмаас үүсч буй тохролтот хагарлаар агшилт явагдаж байна.

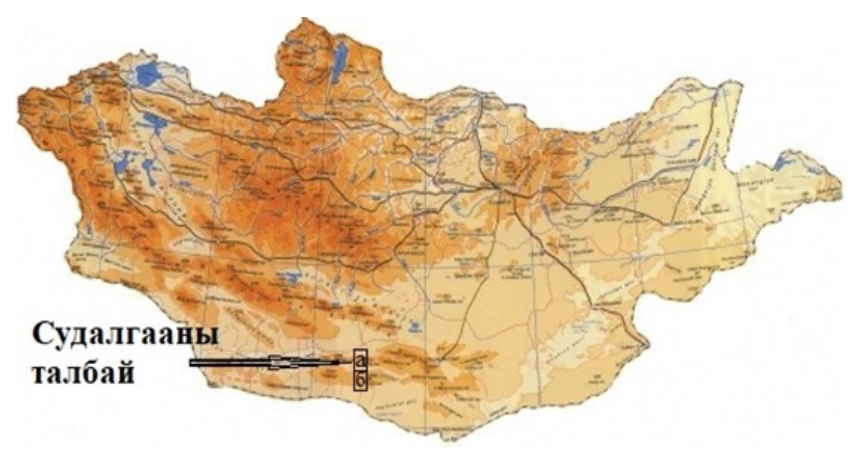

Зураг 2. Судалгааны талбайн байршлын тойм зураг

Энэ районд, сансрын зурагт тайлагдаж байгаa 1-14 дугаартай тохролтот хагарлууд нь хэвтээ чиглэлтэй, шахах тектоник хөдөлгөөний чиглэлд хөндлөн буюу бараг өргөргийн дагуу $90^{\circ}$ суналтай байна. Харин $1,2,3,5,7,9,11,13$ дугаартай хагарлууд нь хойш уналтай буюу эсрэг тохролтот хагарал бол 4, 6, 8, 10, 12, 14 дугаартай урагш уналтай хагарлууд нь тохролтот хагарал буюу уг тектоник хөдөлгөөний эсрэг налуу урагш уналтай юм. Таван загийн хоолой, Дунд голын хоолойн грабенд кайнозой, цэрдийн настай хурдаст янз бүрийн чиглэлтэй шинэхэн тектоник хагарал олноор сансрын зурагт тод тайлагддаг.

Таван загийн хоолойд Х-У зүгт тохорсон, хойш налуу уналтай гурван зэрэгцээ, эсрэг тохролтот хагарлууд тогтоогдсон (Зураг 3). Эдгээр эсрэг тохролтот хагарлаар гипсометрийн түвшингийн хувьд нам буюу газрын доод тал нь гипсометрийн өндөр, газрын дээд тал дээгүүр тохорч гарсан.

Эсрэг тохролтот хагарал-1, солбилцол: ХӨ 4349'51”, 3У 101²7'59’. Дөрөвдөгчийн 


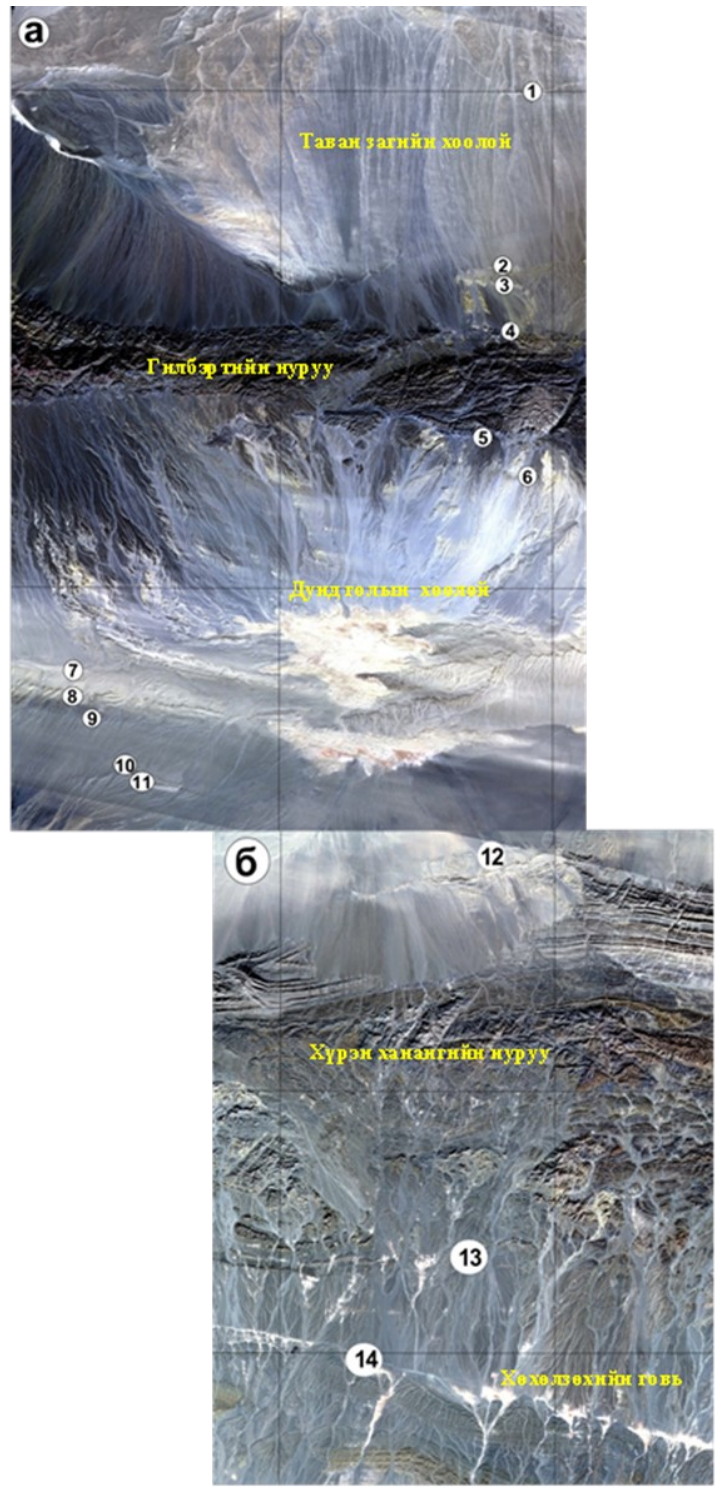

Зураг 3. Эсрэг тохролтот хагарал 1, 2, 3, 5, 7, 9, 11, 13 болон тохролтот хагарал 4, 6, 8, 10, 12, 14 сансрын зурагт харагдах байдал

хурдас дунд илэрсэн ба өргөргийн дагуу суналтай мөргөцөг үүсгэсэн (Зураг 5).

Хагарал сансрын зураг дээр цайвар өнгийн зурвасаар тод тайлагдах ба зарим газар сансрын зурагт муу илэрдэг.

Суналын дагуу урт үргэлжлэх ба заримдаa салбарласан хагарлууд үүсгэнэ. Гилбэртийн нуруунаас эх авсан, хойд зүг рүҮ урсах орчин үеийн аллювийн хурдас бүхий жижиг сайрууд тус хагаралд хөндлөн чиглэлтэй байгаа ба түүгээр урссан ус мөргөцөгт тулаад хоёр тийш сарниж урссан байгаа нь хойноос урагш чиглэлтэй тохоос байгааг баталж өгдөг. Мөн тус хагарал өргөргийн дагуу чиглэлтэй босоо уналтай хагарлаар огтлогдож, 50-60 м амплитуттай баруун гарын шилжээст орсон (Зураг 5).

Эсрэг тохролтот хагарал-2, солбилцол: ХӨ 4342'52”, 3У 101²6’34”. Дөрөвдөгчийн хурдас, дээд цэрдийн Баруунгоёот формац дээгүур гарсан тохоосоос үүссэн уртрагийн дагуу суналтай, 10-15 м өндөртэй мөргөцөг сансрын зурагт тод тайлагддаг (Зураг 6). 1:200000 масштабтай геологийн зурагт дөрөвдөгч болон цэрдийн хурдасны хилийг Үүгээр зурсан байдаг. Тус хагарал нь хөндийн дагуу 15 км орчим урт үргэлжлээд Хонгорын элсээр хучигдсан байдаг.

Эсрэг тохролтот хагарал-3, солбилцол: ХӨ 4342'14", 3У 101²6’42”. Баруунгоёот формацын хурдас дундах тохоос 20-30 м өндөртэй, уртрагийн дагуу суналтай мөргөцөг сансрын зурагт тод тайлагддаг (Зураг 7). Тус хагарал нь суналын дагуу 3-4 км үргэлжлээд сэвсгэр хурдсаар хучигддаг.

Тохролтот хагарал-4 (ХӨ 4340'34”, 3У $101^{\circ}$ 26'05"; Зураг 8) болон эсрэг тохролтот хагарал-5 (ХӨ 43³6’04”, 3У 101²5'23”; Зураг 9) -уудаар Гилбэртийн нуруу шахагдан дээш өндөрсөж байна.

Гилбэртийн нуруу, Хүрэн ханангийн нуруунуудын хооронд орших Дунд голын хоолойн хөндийд уртрагийн дагуу суналтай урагшаа уналтай тохролтот хагарал (хагарал $6,8,10)$, хойшоо уналтай эсрэг тохролтот хагарлууд (хагарал 7, 9, 11) тус тус тайлагддаг.

Тохролтот хагарал-6, солбилцол: ХӨ $43^{\circ}$ 34'44', ЗУ 101²7'22', Гилбэртийн нурууны өвөрт, дээд цэрдийн Баруунгоёот формац дунд хойноос урагш тохорсон мөргөцөг илэрсэн. Тус тохролтот хагарал нь хоёр салбарласан байдаг (Зураг 10). Эсрэг тохролтот хагарал-7, солбилцол: ХӨ $43^{\circ}$ 27'00', 3У 10059'06'. 1:200000 масштабтай геологийн зурагт тохролтот хагарал-7 -гийн хойд тал болох дээд цэрдийн Баруунгоёот формац кайнозойн хурдас дээгүүр тохорсон (Бөхбат нар, 1999) мөргөцөө ҮҮсгэсэн нь зураглагдсан байдаг (Зураг 11). Учир нь цэрдийн хурдаснаас тогтсон уртрагийн дагуу суналтай мөргөцөг нь зарим тохиолдолд 
Ганбаатар, Монголын Геосудлаач 48 (2019) 17-27

DOI: https://doi.org/10.5564/mgs.v0i48.1145

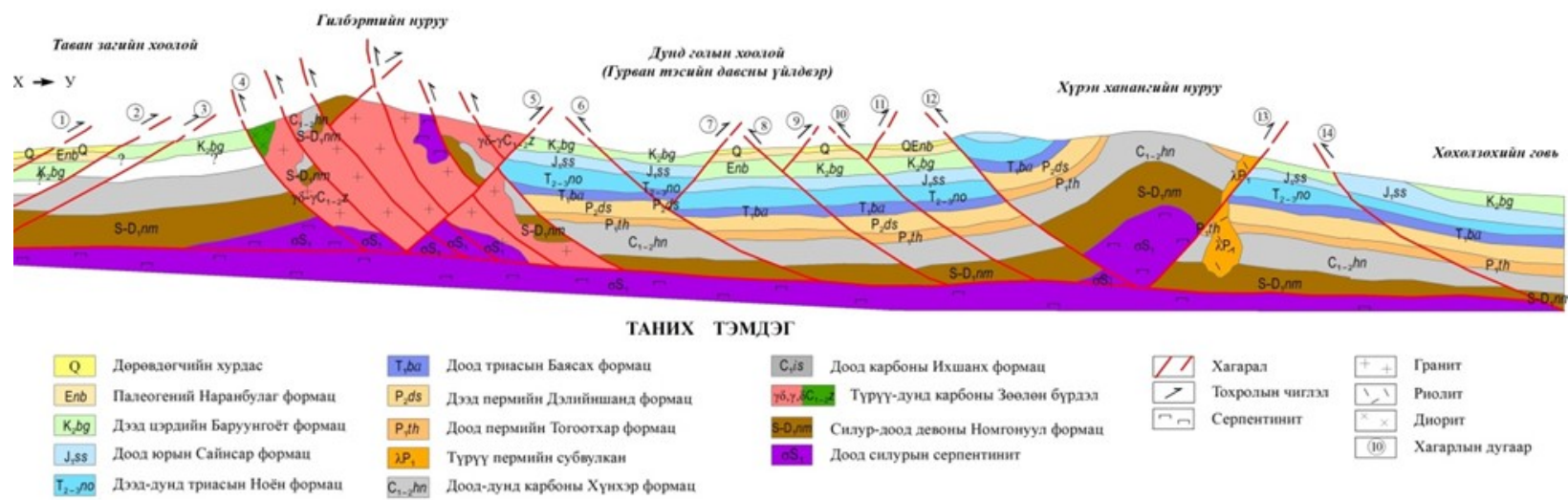

Зураг 4. Таван загийн хоолой, Гилбэртийн нуруу, Дунд голын хоолой, Хүрэн ханангийн нуруун дахь тохролтот болон эсрэг тохролтот хагарлуудыг оролцуулан хийсэн геологийн тойм зүсэлт

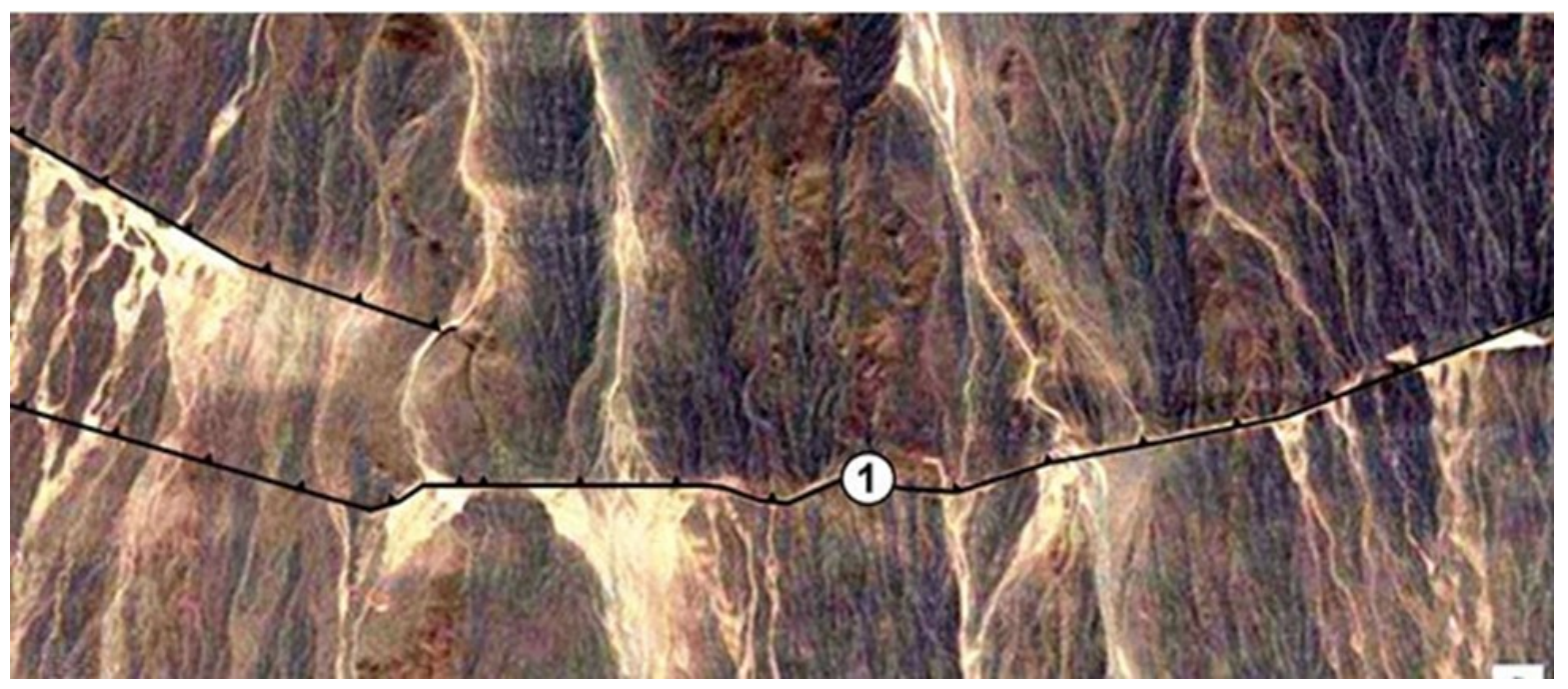

Зураг 5. Дөрөвдөгчийн хурдас дунд үүссэн эсрэг тохролтот хагарал-1 маш тод тайлагддаг

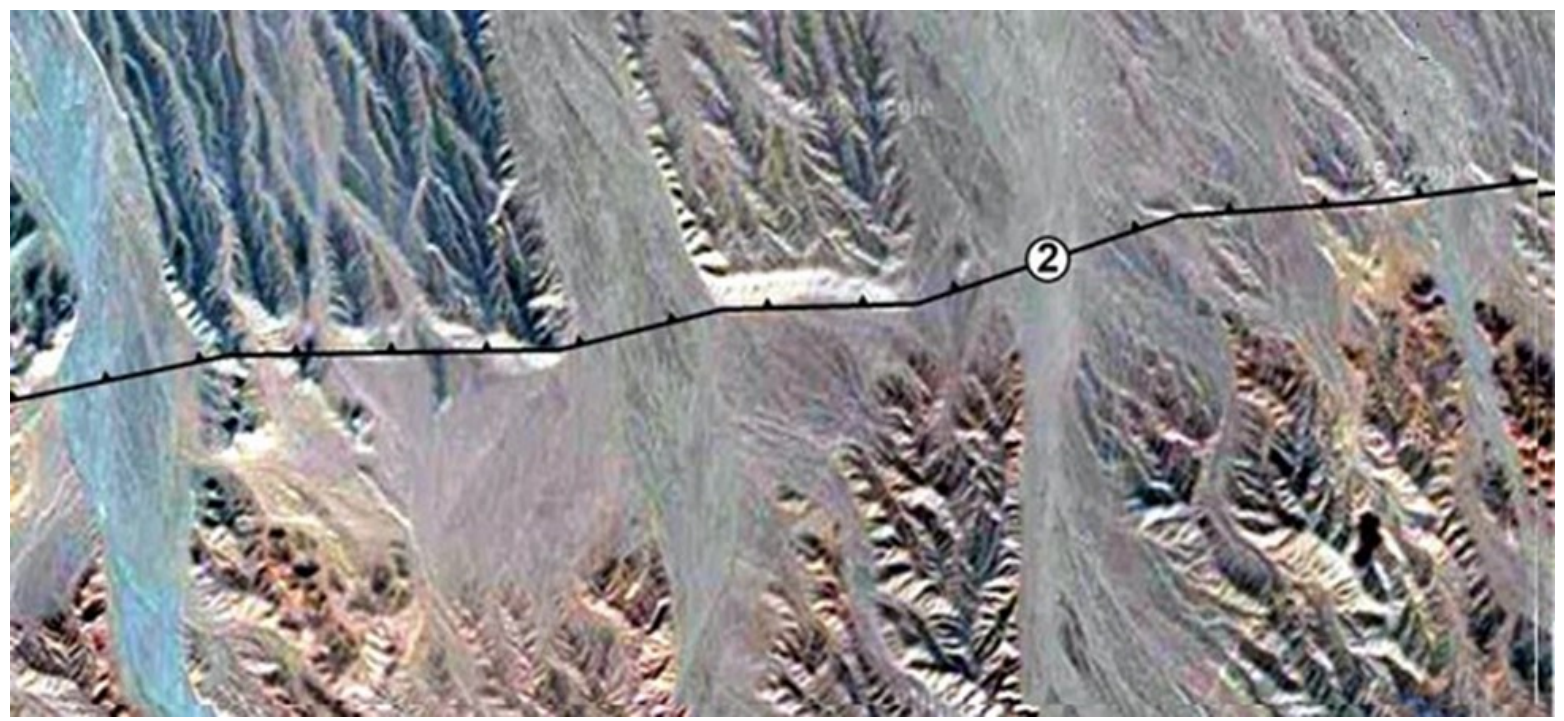

Зураг 6. Эсрэг тохролтот хагарал-2-аар дөрөвдөгчийн хурдас нь дээд цэрдийн настай Баруунгоёот формац дээгүүр тохорсон мөргөцөгийн харагдах байдал 


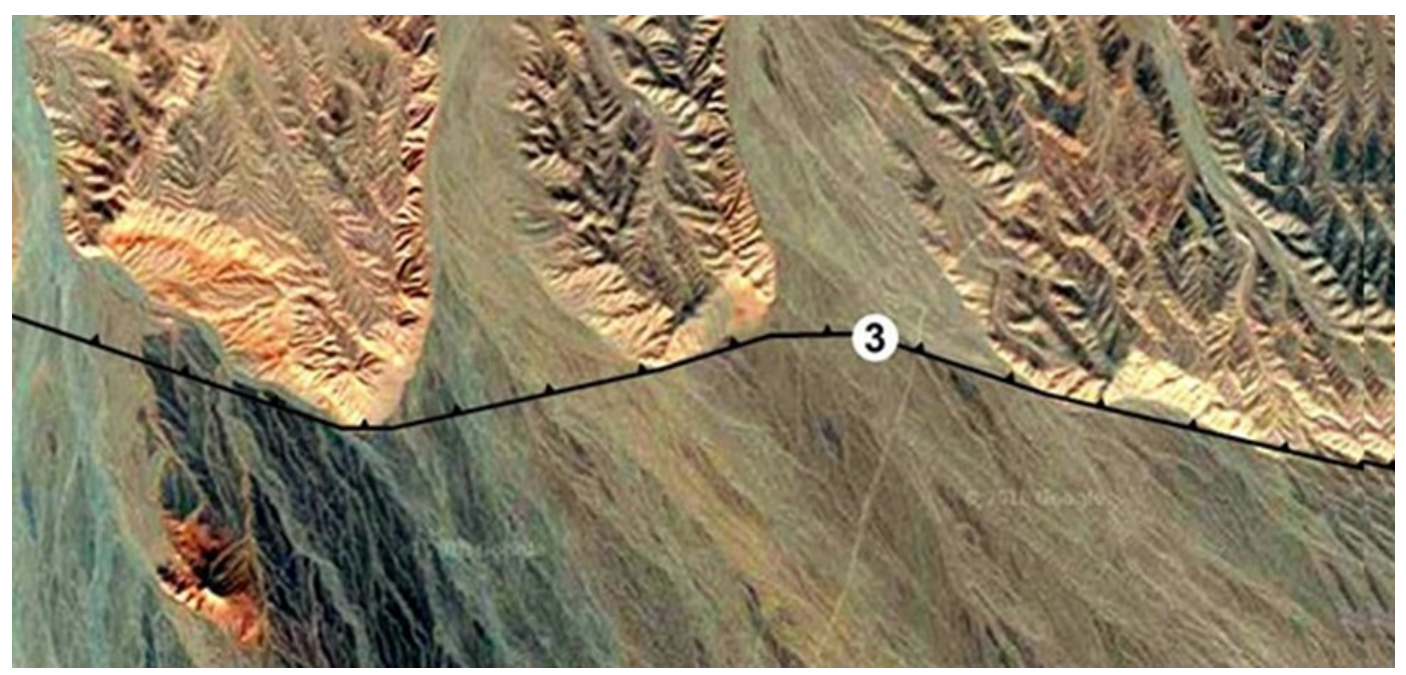

Зураг 7. Дээд цэрдийн настай Баруунгоёот формац дунд үүссэн эсрэг тохролтот хагарал 3-аар хойноос урагш тохорсон мөргөцөгийн харагдах байдал

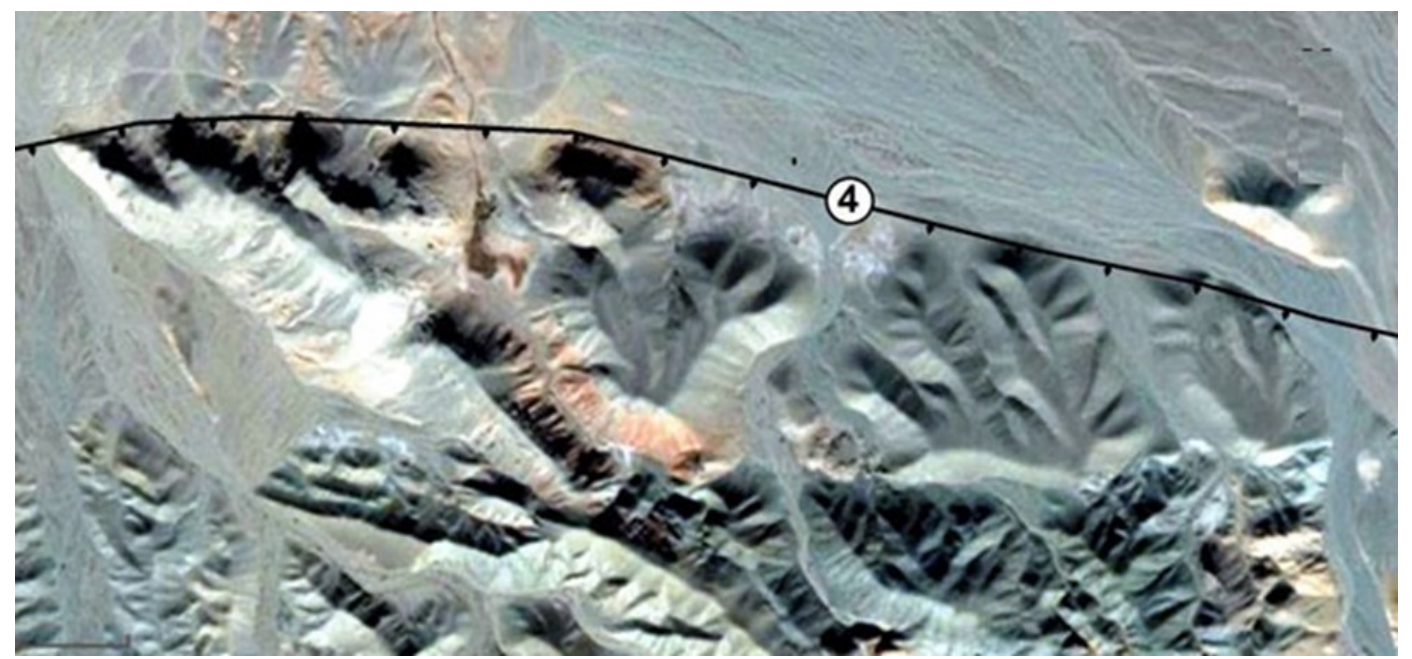

Зураг 8. Тохролтот хагарал-4. Гилбэртийн нурууны ар талд дээд цэрдийн Баруунгоёот формац дээгүүр түүнээс эртний настай хурдас чулуулаг өмнөөс хойш тохорч гипсометрийн түвшин огцом өндөрссөн байдал

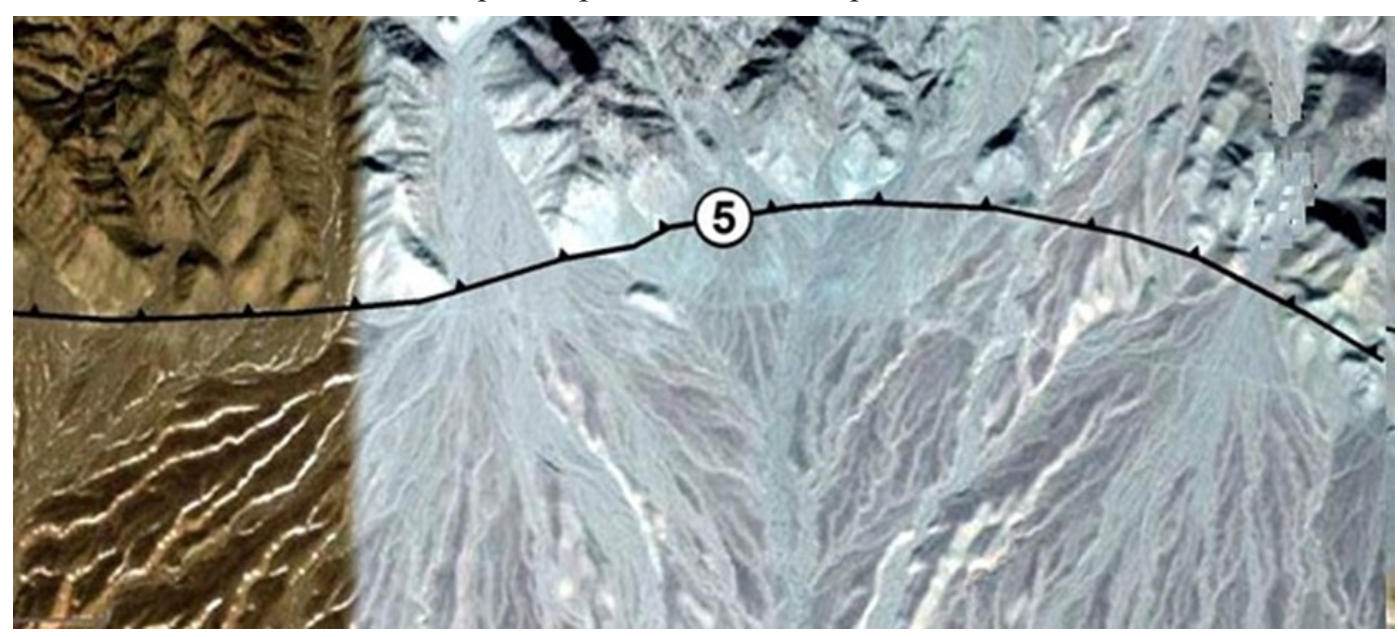

Зураг 9. Эсрэг тохролтот хагарал-5. Гилбэртийн нурууны өвөр хэсэгт дээд цэрдийн Баруунгоёот формац дээгүүр түүнээс эртний настай хурдас чулуулаг хойноос урагш тохорч гипсометрийн түвшин огцом өндөрссөн. 


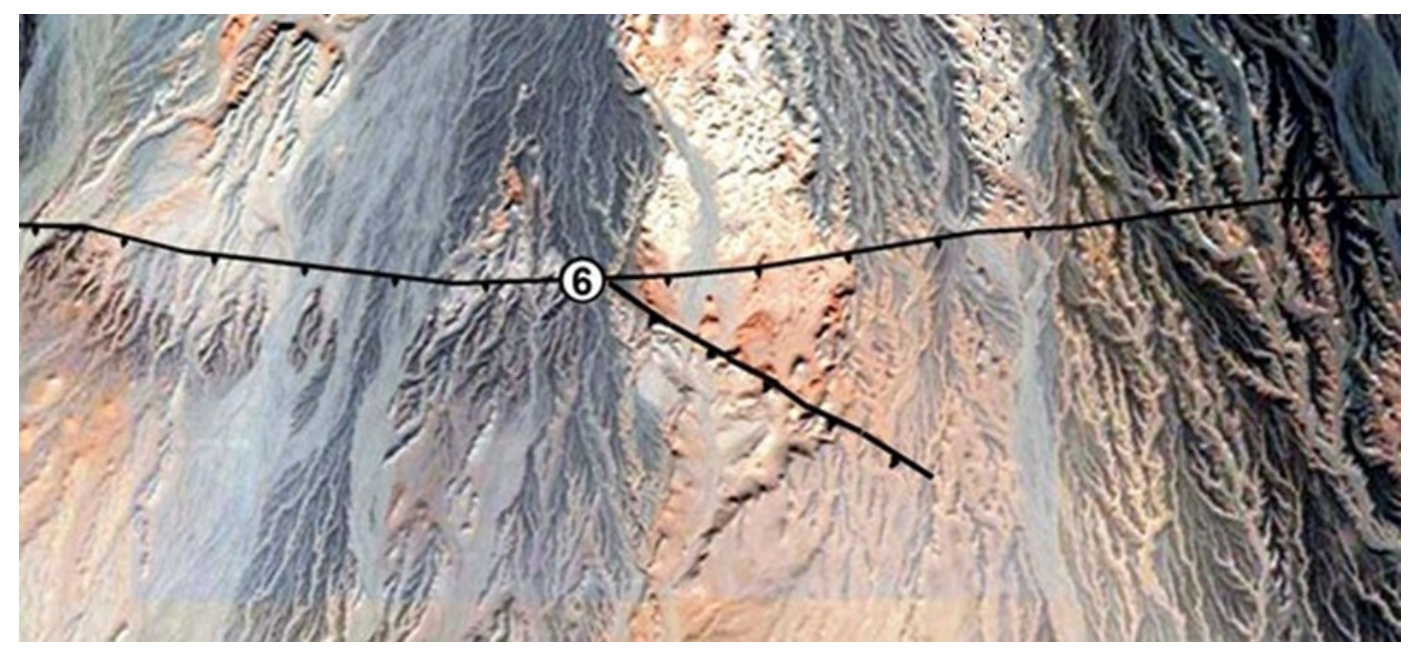

Зураг 10. Дээд цэрдийн настай Баруунгоёот формац дунд үүссэн тохролтот хагарал-6 аар өмнөөс хойш тохорсон мөргөцөгийн харагдах байдал

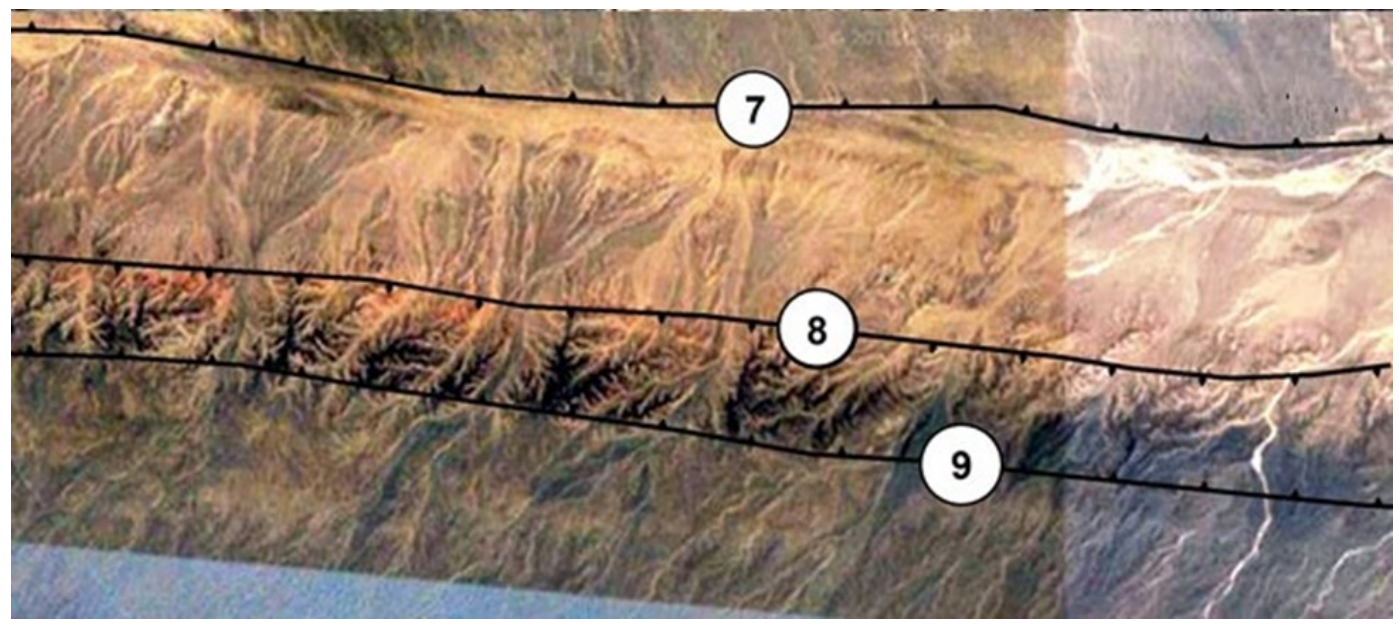

Зураг 11. Эсрэг тохролтот хагарал-7 -оор дээд цэрдийн Баруунгоёот формацаар урагш тохорсон мөргөцөг үүсэж голын эрэг болсон бол тохролтот хагарал-8, эсрэг тохролтот хагарал-9-ээр палеогены настай Наранбулаг формац дээш шахагдан гарч дөрөвдөгчийн хурдас дунд тектоникийн цонх үүсгэсэн байдал

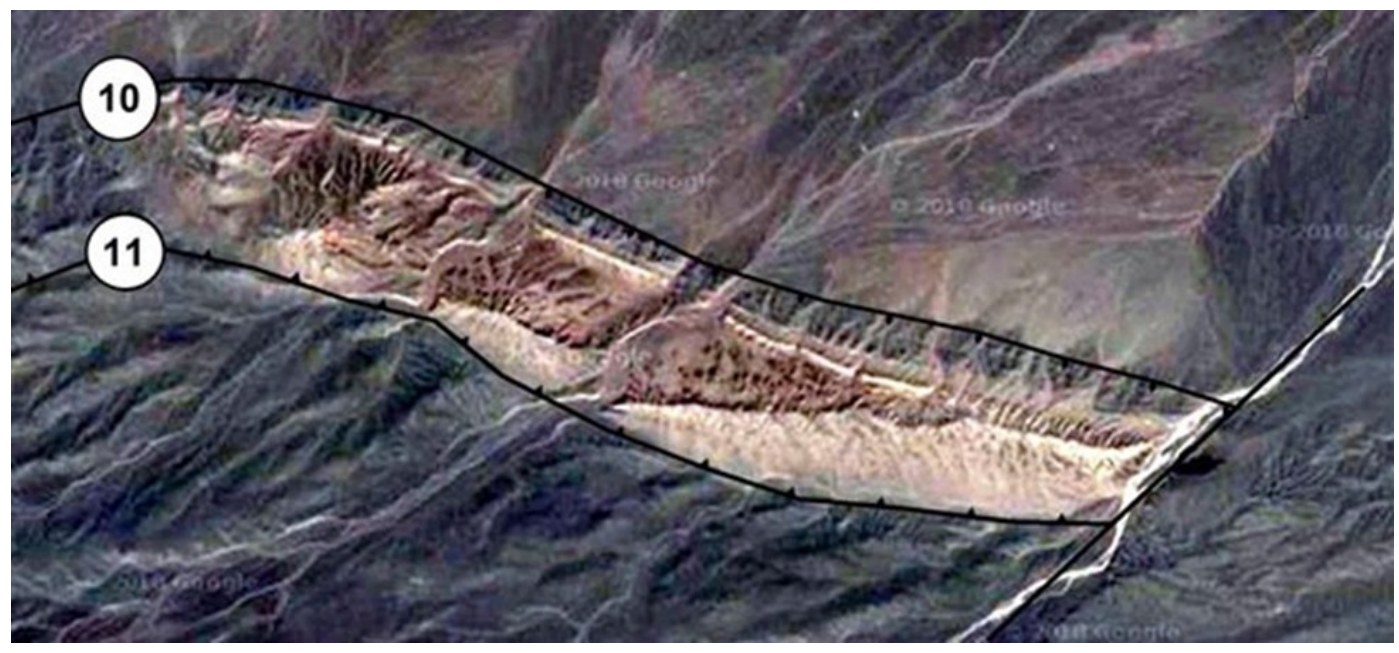

Зураг 12. Тохролтот хагарал-10, эсрэг тохролтот хагарал-11-ээр дээд цэрдийн Баруунгоёот формац шахагдан дээш гарч, дөрөвдөгчийн хурдас дунд тектоникийн цонх үүсгэсэн байдал 


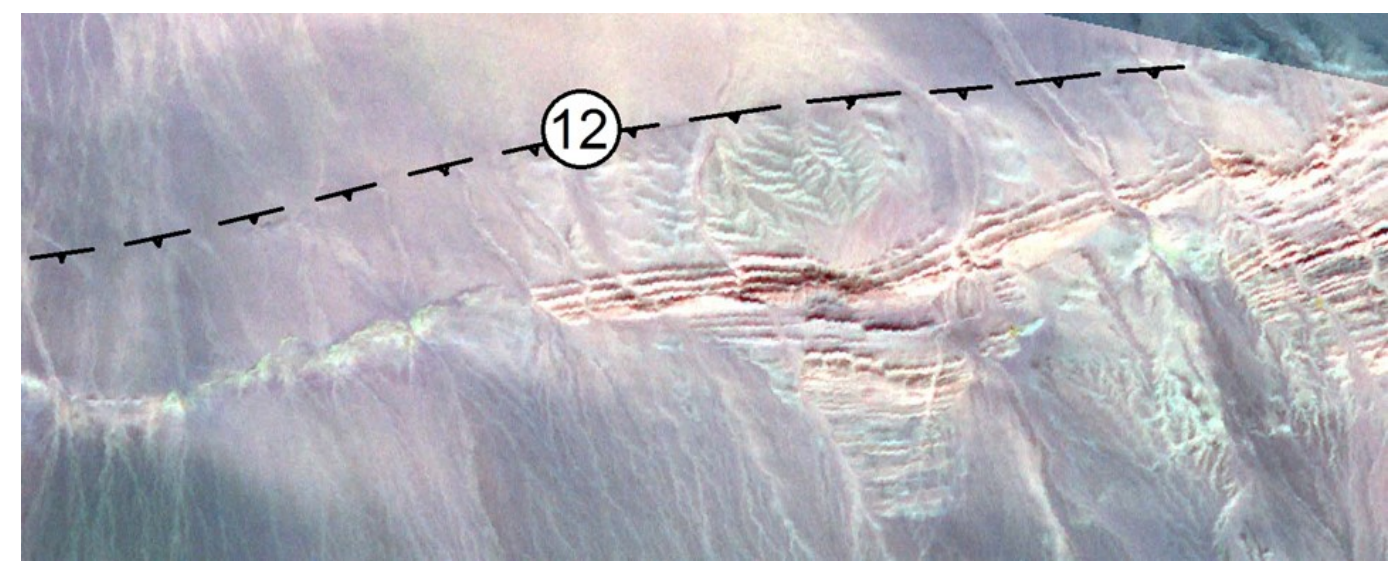

Зураг 13. Тохролтот хагарал-12-ын харагдах байдал. Дээд цэрдийн настай хурдас кайнозойн хурдас дээгүүр тохорч байгаа

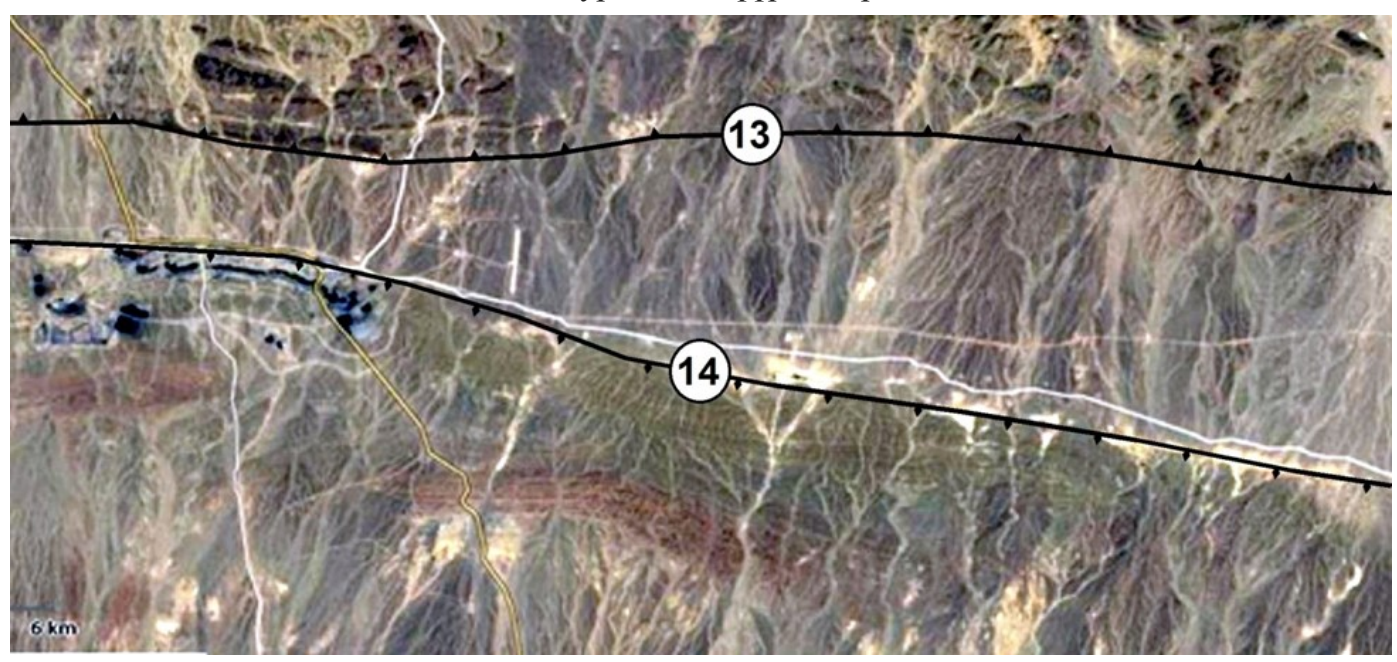

Зураг 14. Эсрэг тохролтот хагарал-13, тохролтот хагарал-14 сансрын зурагт харагдах байдал. ТүрүҮ пермийн настай субвулкан биет болон доод пермийн настай Тогоотхар формац цэрдийн хурдас дээгүүр хойноос урагш тохорсон бол дунд-дээд триасын настай

Ноён формац өмнөөс хойш цэрдийн настай Баруунгоёот формац дээгүүр тохорсон

Дунд голын хөндийн хойд эрэг болж байгаа нь түүний тохрол болох нэг шинж болдог.

Тохролтот хагарал-8, солбилцол: ХӨ $43^{\circ}$ 26'03", 3У 10058'55" (Зураг 11), эсрэг тохролтот хагарал-9, солбилцол: ХӨ 4325, 26”, ЗУ 10058'44” (Зураг 11). Эдгээр хагарлууд нь Дунд голын хөндийн төв хэсгийн өмнөд эргийг эмжиж, уртрагийн дагуу суналтай урт нарийхан тектоникийн цонх үүсгэсэн палеогений Наранбулаг формацын хурдсын хоёр талаар орших (Бөхбат нар, 1999) ба уг хурдас нь дөрөвдөгчийн хурдсаас өндөр мөргөцөг үүсгэж байгаа нь тайлагдсан. Тектоникийн цонхны хойд талын мөргөцөг буюу тохролтот хагарал-8-аap Үүссэн уртрагийн дагуу суналтай мөргөцөг нь зарим тохиолдолд Дунд голын өмнөд эрэг болж байна. Дээрх тектоникийн цонх нь тохролтот хагарал-8, эсрэг тохролтот хагарал-9 -өөр дээш шахагдан гарсан блокоос тогтоно.

Тохролтот хагарал-10, солбилцол: ХӨ $43^{\circ}$ 22'37', 3У $101^{\circ} 07^{\prime} 02^{\prime \prime}$, эсрэг тохролтот хагарал-11, солбилцол: ХӨ 4322'12”, ЗУ 10107'34” (Зураг 12). Эдгээр хагарлаар дөрөвдөгчийн хурдас дунд Баруунгоёот формацын тектоникийн цонх илэрсэн.

Тохролтот хагарал-12, солбилцол: ХӨ $43^{\circ}$ 17'56", 101²1'32" (Зураг 13), эсрэг тохролтот хагарал-13, солбилцол: ХӨ $43^{\circ}$ 03'07', 3У 101¹4'20” (Зураг 
хагарлуудаар Хүрэн ханангийн нуруу шахагдан дээш өндөрсөж байна.

Хүрэн ханангийн нурууны өвөрт тохролтот хагарал-14 (Зураг 14), солбилцол: ХӨ $42^{\circ}$ $58^{\prime} 25^{\prime \prime}$, 3У $101^{\circ} 27^{\prime} 18^{\prime \prime}$. Уг хагарлаар хойш чиглэсэн тохоос явагдаж байгаа нь сансрын зурагт маш тод тайлагддаг. Энд дунд-дээд триасын настай Ноён формац дээд цэрдийн настай Баруунгоёот формац дээгүүр тохорч байгааг С.Бөхбат нар тогтоосон байдаг (Бөхбат нар, 1999).

\section{ХЭЛЭЛЦУУЛЭГ}

Гилбэртийн нуруун дунд, түүнд ташуу $3 Х$ чиглэлтэй хагарлаар өмнөх насны хурдас чулуулагтай хиллэсэн цэрдийн хурдас бүхий жижиг грабенүүд байдаг. Энэ нь Гилбэртийн нуруу болон дээрх ташуу чиглэлтэй хагарлуудаар хиллэсэн хөндий нь цэрдийн галаваас өмнө үүссэн бөгөөд түүнд цэрдийн хурдас хуримтлагдсан байж болох юм. Харин Хүрэн ханангийн нуруу нь цэрдийн галавын үед үүсээгүй, эсвэл дөнгөж үүсч байсан ба үүнийг цэрдийн хурдасны үлдэгдэл гарш тус нурууны тэнхлэгийн дагуу тасалдалтайгаар урт үргэлжилсэн байгаагаар тайлбарлаж болно. Гилбэртийн нуруунд доод силурын серпентинитын меланжууд илэрсэн нь (Зураг 4) түүнийг Хүрэн ханангийн нуруунаас түрүүлж үүссэн, илүҮ хурдтай өргөгдөлд орсоныг харуулдаг. Гилбэртийн нуруунд хэвтээ чиглэлтэй тектоник хүчний үйлчлэлээр үүссэн харьцангуй эртний тохролтот, эсрэг тохролтот хагарлууд нь энэ ороген бүсийн суурь болох доод силурын настай серпентинитыг дээш шахан гаргаж байгаа ба Үүнийг ихэвчлэн эртний настай гүний хагарал гэж ойлгодог байна.

\section{ДҮГНЭЛТ}

Манай орны баруун, баруун өмнөд, Хятад улсын баруун хойд хэсэгт өмнөөс хойш, хойш чиглэлтэй үйлчилж буй хэвтээ чиглэлтэй шахах тектоник хөдөлгөөнөөр дээрх бүс нутаг бүхэлдээ хойш гулсаж байгаa болно. Хэвтээ чиглэлтэй шахах тектоник хүчнээс ҮҮдэлтэй хөдөлгөөний улмаас агшилт явагдаж, хавтан зузаарч, нурууд улам өндөрсөж Таван загийн хоолой, Гилбэртийн нуруу, Дунд голын хоолой, Хүрэн ханангийн нуруу өөр хоорондоо ойртож байна. Мөн энэ хөдөлгөөнөөс болж Монгол улсын баруун өмнөд хэсгийн улсын тэмдэглэгдсэн хилийн зурвас хойшоо, Байгаль нуурын рифтийн тэлэлтээс болоод хойд хил зүүн урагшаа нүүж байна гэсэн дүгнэлт хийж байна.

Грабенуудад шинээр тохрол үүсч байгаа нь ирээдүйн уул, нуруудын эхлэл боайж болох юм. Гүний хагарал гэж нэрлэгдээд байгаа эртний настай чулуулгийг агуулж байгаа хагарлууд нь зөвхөн үүссэн цаг хугацааны хувьд бусад хагарлаас эртний байж болох юм.

\section{АШИГЛАСАН МАТЕРИАЛ}

Argand, E. 1916. Sur 1'arc des Alps occidentales: Eclogae Geologicae Helvetiae, v. 14, 141-191.

Bayasgalan, A. 1995. Application of Remote Sensing Techniques for the Regional Geology and Neotectonics of the Gobi Altay Range, South-western Mongolia. ITC, 105 p.

Bayasgalan, A., Olziybat, M., Enhtuvshin, B., Molnar, P., Bayarsayhan, Ch., Hudnut, K.W., Lin, J. 1997. Kurushin R. A. (Ed.) The Surface Rupture of the 1957 Gobi-Altay, Mongolia, Earthquake. Geological Society of America, Special paper 320, 143 p.

Buxtorf, A. 1916. Prognosen und Befunde beim Hauensteinbasis-und Grenchenburg-tunnel und die Bedeutung der letzteren for die Geologie des Juragebirges: Naturforschung Gesellschaft Basel Verhandlungen, v. 27, p. 184 -254 .

Ganbaatar, L. 2015. Focal mechanism in Mongolia and its surroundings. Mongolian Geoscientist 42, 52-62.

Kusky, T.M., Zhai, M., Xiao, W. 2010. The evolving continents: understanding processes of continental growth - introduction Geological Society, London, Special Publications, 338 (1), 1-6.

Landgraf, A., Kьbler, S., Hintersberger E., Stein S. 2017. Seismicity, Fault Rupture and Earthquake Hazards in Slowly Deforming Re- 
gions. Geological Society of London, Special publication vol. 432.

McConnell, R.G. 1887. Report on the geological structure of a portion of the Rocky Mountains: Geological Survey of Canada Summary Report for 1986, v. 2, p. 41.

Owen, L.A., Windley, B., Cunningham, W.D., Badamgarav, J., Dorjnamjaa, D. 1997. Quaternary alluvial fans in the Gobi of southern Mongolia: Evidence for neotectonics and climate change. Journal of Quaternary 12(3), 239-252.

Price, R.A. 1981. The Cordilleran foreland thrust and fold belt in the southern Canadian Rocky Mountains. Geological Society, London, Special Publications. 9. 427-448. 10.1144/GSL.SP.1981.009.01.39.

Rich, J.L. 1934. Mechanics of Low-angle Overthrust Faulting as Illustrated by Cumberland Thrust Block, Virginia, Kentucky, and Tennessee. Bulletin of the American Association of Petroleum Geologists 18(12), 1584-1596.

Robert, D., Hatcher, Jr. 2007. Confirmation of Thin-skinned Thrust Faulting in Foreland Fold-Thrust Belts and Its Impact on Hydrocarbon Exploration: Bally, Gordy, and Stewart, Bulletin of Canadian Petroleum Geology, 1966*. Search and Discovery Article \#70034 (2007)

Roberts, N.M.W., Cunningham, D. 2008. Automated alluvial fan discrimination, Quaternary fault identification, and the distribution of tectonically reactivated crust in the Gobi Altai region, southern Mongolia. International Journal of Remote Sensing, 29(3). 69576969. 10.1080/01431160802220227.

Safford, J.M. 1856. A geological reconnaissance of the State of Tennessee: Nashville, Mercer, $164 \mathrm{p}$.
Tian, Zh., Xiao, W., Windley, B., Zhang, J., Zhang, Zh., Song, D. 2016. Carboniferous rifted arcs leading to an archipelago of multiple arcs in the Beishan-Tianshan orogenic collages (NW China). International Journal of Earth Sciences. 10.1007/s00531-016-1428-7.

Törnebohm, A.E., 1872 .En geognostisk profil öfver den skandinaviska fjällryggen mellan Östersund och Lavanger: Sveriges Geologiska Undersökning, v. 6, 24 p

Woldai, Ts., Bayasgalan, A. 1998. Interpretation of satellite data related to neotectonic activities connected with earthquakes in western Mongolia. ISPRS 1998. Proceedings of the ISPRS commission VII symposium, Vol. XXXII, part 7. Resource and environmental monitoring, 615-624.

Woldai, Ts., Dorsjuren, J. 2004. Application of remotely sensed data for neotectonics study in western Mongolia. ISPRS 2004: Proceedings of the XXth ISPRS congress, Geoimagery bridging continents, Vol. VI WG VI/ V. 1192-1196.

Бадарч, Г., Баатар, Х., Баяржаргал, Х. 2003. Монгол Улсын 1:200000 масштабтай геологийн зургийн легенд, түүний тайлбар бичиг. Баруун Өмнөд Монголын сери, 5560-9ф.

Бөхбат, С., Наранбаатар, Ц., Бадарч, Г. 1999. Нэмэгтийн талбайд 1996-1997 онд гүйцэтгэсэн 1:200000-ны масштабын геологийн зураглал. 5246ф

Буянбаатар, Ч., Золжаргал, А., Билгүүнбаатар Х., Жамьяндорж, Ө., Бүрэнбаяр, Г. 2010. УГЗ-200 Өмнөд Монгол III төслөөр 20072009 онуудад гүйцэтгэсэн 1:200,000-ны иж бүрдэл зураглал. 6326ф . 